\title{
Eksperimentasi Model TSTS pada Operasi Hitung Aljabar Ditinjau dari Kecerdasan Emosional Siswa SMPN 1 Ngronggot
}

\author{
Reza Dimas Pravangasta Perdana ${ }^{(1)}$ \\ ${ }^{1}$ STKIP PGRI Nganjuk \\ Email: ${ }^{1}$ rezadimas@stkipnganjuk.ac.id
}

\section{Tersedia Online di \\ http://www.jurnal.unublitar.ac.id/ index.php/briliant}

\begin{tabular}{l}
\hline Sejarah Artikel \\
\hline Diterima pada 25 April 2018 \\
Disetuji pada 10 Mei 2018 \\
Dipublikasikan pada $13 \mathrm{Mei}$ \\
2018 Hal. 260-267 \\
\hline
\end{tabular}

\section{Kata Kunci:}

tsts, pembelajran langsung, aljabar, prestasi belajar, emotional intelligence,

\section{DOI:}

http://dx.doi.org/10.28926/briliant .v3i2.182

\begin{abstract}
Abstrak: Tujuan penelitian ini adalah untuk mengetahui pengaruh model pembelajaran terhadap prestasi belajar matematika ditinjau dari kecerdasan emosi siswa (EI). Model pembelajaran yang digunakan adalah Two Stray Two Stray (TSTS) dan pembelajaran langsung. Penelitian ini menggunakan eksperimen semu. Dengan popilasi siswa kelas VII SMP Negeri di Nganjuk. Anova dua jalan dengan desain faktorial $2 \times 3$. Berdasarkan analisis, dapat disimpulkan: (1) siswa yang diberi TSTS memiliki prestasi lebih baik daripada mereka yang diberi pembelajaran langsung (2) tinggi Siswa EI memiliki prestasi yang lebih baik dari pada siswa EI menengah dan rendah, EI menengah memiliki prestasi sama dengan EI rendah, (3) Siswa dengan EI rendah pada model pembelajaran TSTS memiliki prestasi lebih baik dibandingkan pada model pembelajaran langsung, (4) Siswa yang dikenai model pembelajaran tipe TSTS dengan EI tinggi memiliki prestasi lebih baik dibandingkan EI rendah, sedangkan siswa EI sedang lebih baik dibandingkan siswa EI rendah. Siswa yang dikenai model pembelajaran langsung pada EI tinggi memiliki prestasi lebih baik dibandingkan siswa dengan EI sedang dan rendah.
\end{abstract}

Pengembangan potensi manusia suatu negara sangat berpengaruh pada kemajuan pendidikan negara tersebut..Menurut Permendiknas No. 22 tahun 2006, yaitu pendidikan nasional berfungsi untuk mengembangkan potensi yang dimiliki siswa, sehingga menjadi manusia yang memiliki kemampuan dan kecakapan hidup.

Matematika adalah bidang pendidikan yang mempengaruhi potensi diri manusia. Dalam pelajaran matematika dianggap mampu melatih siswa dalam berpikir kritis, sistematis, dan logis sehingga berpengaruh pada kualitas dan potensi manusia dalam kehidupan. Namun sulitnya pelajaran matematika masih sering dikeluhkan banyak orang. Supartono dalam Zulkardi dan Purwoko (2009: 62) menyatakan bahwa masih banyak siswa yang mengalami kesulitan dalam mempelajari matematika. Kenyataan tersebut berimbas pada rendahnya prestasi siswa.

Rendahnya hasil belajar juga dapat dilihat berdasarkan klasifikasi nilai matematika siswa hasil ujian nasional tingkat SMP di Kabupaten Nganjuk. Dapat diketahui berdasarkan data PAMER UN 2017 bahwa matematika pada SMP mendapatkan yang hasil yang kurang baik dengan nilai rata-rata 42,22. Kurangnya pemahaman materi diduga menjadi penyebab rendahnya nilai rata-rata ujian 
nasional. Rendahnya tingkat penguasaan materi siswa SMPN 1 Ngronggot 2016/2017 khususnya pada operasi hitung aljabar.

Operasi hitung aljabar dalah materi yang menjadi dasar dari materimateri berikutnya. Akantetapi masih ditemukan banyak hal yang menghambat siswa mampu memahami materi tersebut dengan baik. Adapun hasil penelitian yang ditunjukkan Seng (2010) menunjukkan bahwa banyak, many students still lack a good conceptual understanding of algebraic expressions. Egodawatte (2009) juga menjelaskan adanya kesalahan terkait penyelesaian permasalahan aljabar yang dinyatakan dengan soal cerita dan ungkapan aljabar memiliki presentasi yang paling tinggi dibandingkan kesalahan terkait persamaan dan variabel. Beberapa pendapat diatas dapat dimbil kesimpulan masalah sering dialami siswa pada materi aljabar banyak dikarenakan kurang matangnya pemahaman siswa dalam pola pikir abstrak dalam aljabar.

Rendahnya prestasi belajar matematika siswa dapat disebabkan banyak faktor. Menurut Herman Hudojo (2005:6) keberhasilan belajar matematika bergantung kepada proses belajarnya. Dalam kenyataannya guru lebih suka dan sering menggunakan model pembelajaran langsung. Guru menjadi pusat pembelajaran dan siswa kurang terlibat dalam proses pembelajaran, akibatnya siswa kurang aktif dan kurang mengembangkan diri. Beberapa perbaikan diperlukan dalam proses pembelajaran demi meningkatkan pemahaman matematika siswa, salah satu diantaranya perbaikan pada model pembelajaran.

Operasi bentuk ajabar adalah materi yang mengandung unsur abstrak didalamnya sehingga memerlukan pemahaman konsep secara bermakna. Dalam praktek justru kurangnya perhatian dan penyesuaian berakibat pada keberhasilan pemahaman siswa. Keberhasilan belajar siswa bisa dipengaruhi oleh berbagai macam kecerdasan antara lain kecerdasan intelektual atau kecerdasan emosional. Akibatnya banyak siswa yang tidak dapat belajar secara maksimal materi yang diajarkan oleh guru, sehingga menjadikan kurang bermaknanya materi dan konsep yang diajarkan. Dengan mempertimbangkan kemampuan dan kecerdasan masingmasing siswa diharapkan mampu diaplikasikan dalam proses pembelajaran.

Kurang aktifnya siswa juga menjadi salah satu sebab rendahnya pemahaman siswa. Nyman (2015) menyatakan bahwa terkadang mereka harus terlebih dahulu mendapatkan lebih halangan dalam kerja keras dan memahami dasar-dasar sebelum mereka merasa dirinya hasil. Dengan kata lain siswa harus berusaha sendiri sehingga bisa dipahami dengan baik.

Pembelajaran kooperatif adalah suatu model yang dikembangkan untuk membentuk suatu pembelajaran yang berpusat pada siswa. Pasifnya siswa dapat diatasi dengan model pembelajaran kooperatif yang menonjolkan aktifits siwa dalam proses pembelajaran. Ajaja dan Eravwoke (2010) menyatakan bahwa pembelajaran kooperatif adalah pilihan yang layak diantara model pembelajaran yang lain untuk mengajar ilmu di sekolah menengah.

Model pembelajaran kooperatif yang cocok dalam mengatasi masalah siswa khususnya pada materi operasi hitung aljabar antara lain model pembelajaran kooperatif tipe TSTS (Two Stay Two Stray). Model pembelajaran kooperatif tipe TSTS praktek sederhanaya dua orang pada masing-masing kelompok bertugas sebagai tuan rumah yang akan melayani tamu dari kelompok lain, dan dua yang lain bertugas sebagai tamu untuk mencari analisa dari kelompok lain sesuai dengan permasalahan yang sedang dibahas. Proses diskusi 
yang berulang memungkinkan siswa mengkonstruksi konsep yang dipelajari dengan membandingkan dengan teman ataupun kelompok lain. TSTS merupakan sistem pembelajaran kelompok dengan tujuan agar siswa dapat saling bekerja sama, bertanggung jawab, saling membantu memecahkan masalah, dan saling mendorong satu sama lain untuk berprestasi.

Setiap siswa mempunyai kecerdasan yang berbeda dimana akan mempengaruhi pemahaman. Kecerdasan yang dikatakan mempengaruhi hasil belajar selain IQ (Kecerdasan Intelektual) adalah EQ (Kecerdasaan Emosional). Maria Cong Abdullah, et al (2004) menyatakan bahwa dengan kecerdasan emosional yang tinggi, murid tidak hanya akan sukses di sekolah tetapi juga akan berkembang menjadi individu yang mampu menyesuaikan diri dengan masyarakat. Kecerdasan emosional sangat berhubungan dengan keberhasilan anak termasuk prestasi di sekolah.. Nwadinigweand Azuka-Obieke (2012: 395-401) menunjukkan ada hubungan positif antara kecerdasan emosional dan prestasi akademik.

Tujuan Penelitian ini adalah (1) Untuk mengetahui manakah yang memberikan prestasi belajar yang lebih baik, siswa yang dikenai model pembelajaran TSTS atau model pembelajaran langsung; (2) Untuk mengetahui manakah yang memberikan prestasi belajar yang lebih baik, siswa yang memiliki kecerdasan emosional tinggi, sedang atau rendah; (3) Untuk mengetahui siswa yang memiliki kecerdasan emosional tinggi, sedang, dan rendah, manakah yang mempunyai prestasi belajar matematika yang lebih baik, siswa yang dikenai model pembelajaran TSTS atau model pembelajaran langsung; (4) Untuk mengetahui siswa yang dikenai model pembelajaran TSTS atau model pembelajaran langsung, manakah yang mempunyai prestasi belajar matematika yang lebih baik, siswa yang memiliki kecerdasan emosional tinggi, sedang atau rendah.

\section{METODE}

Berdasarkan permasalahan yang diteliti, jenis penelitian yang digunakan pada penelitian ini adalah penelitian eksperimental semu dengan desain faktorial $2 \times 3$ yang disajikan dalam

Tabel 1 Desain Fatorial 2x3

\begin{tabular}{|l|c|c|c|}
\hline \multirow{2}{*}{$\begin{array}{c}\text { Model Pembelajaran } \\
(\mathbf{A})\end{array}$} & \multicolumn{3}{|c|}{ Kecerdasan Emosional $(\mathbf{B})$} \\
\cline { 2 - 4 } & Tinggi $\left(\boldsymbol{b}_{\mathbf{1}}\right)$ & Sedang $\left(\boldsymbol{b}_{\mathbf{2}}\right)$ & $\operatorname{Rendah}\left(\boldsymbol{b}_{\mathbf{3}}\right)$ \\
\hline TSTS $\left(\boldsymbol{a}_{\mathbf{1}}\right)$ & $(a b)_{11}$ & $(a b)_{12}$ & $(a b)_{13}$ \\
\hline Langsung $\left(\boldsymbol{a}_{\mathbf{2}}\right)$ & $(a b)_{21}$ & $(a b)_{22}$ & $(a b)_{23}$ \\
\hline
\end{tabular}

Populasi dalam penelitian ini adalah seluruh siswa kelas VII SMP Negeri 1 Ngronggot di Kabupaten Nganjuk. Pengambilan sampel dalam penelitian ini dilakukan dengan cara random sampling. Setelah dilakukan sampling diperoleh Kelas VII-A, VII-C, VII-E, VII-F

Penelitian ini menggunakan 2 variabel bebas dan 1 variabel terikat. Variabel bebas meliputi model pembelajaran dan kecerdasan emosional, sedangkan variabel terikatnya adalah prestasi belajar matematika. Untuk 
mengumpulkan data digunakan metode tes, metode angket dan metode dokumentasi.

Sebelum melakukan eksperimen, dilakukan uji normalitas, homogenitas dan uji keseimbangan terhadap data kemampuan awal matematika menggunakan anava satu jalan dengan sel tak sama, sedangkan untuk data prestasi belajar matematika dianalisis menggunakan analisis variansi dua jalan dengan sel tak sama setelah dilakukan uji normalitas dan homogenitas terlebih dahulu. Uji normalitas untuk data kemampuanawal dan data prestasi belajar dilakukan menggunakan metode Lilliefors dan uji homogenitas variansi populasi menggunakan metode Bartlett. Uji hipotesis menggunakan analisis variansi dua jalan dengan sel tak sama. Uji lanjut pasca anava menggunakan metode Scheffe, apabila hasil analisis variansi menunjukkan bahwa hipotesis nol ditolak.

\section{HASIL}

Hasil uji prasyarat analisis menyimpulkan bahwa semua sampel berasal dari populasi yang berdistribusi normal dan mempunyai variansi yang sama. Berdasarkan hasil uji keseimbangan disimpulkan bahwa sampel dari populasi siswa yang dikenai model pembelajaran TSTS, dan langsung dalam keadaan seimbang.

Hasil perhitungan analisis variansi dua jalan dengan sel tak sama menunjukkan bahwa: (1) H $\neg 0$ A ditolak berarti terdapat perbedaan prestasi belajar matematika antara siswa yang mendapatkan model pembelajaran TSTS, dan langsung, (2) $\mathrm{H} \neg 0 \mathrm{~B}$ ditolak berarti terdapat perbedaan prestasi belajar matematika antara siswa dengan kecerdasan emosional tinggi, sedang dan rendah (3) $\mathrm{H} \neg 0 \mathrm{AB}$ ditolak berarti terdapat interaksi antara model pembelajaran dan kecerdasan emosional siswa terhadap prestasi belajar matematika siswa.

Tabel 2 Rangkuman Rerata Sel dan Rerata Marginal

\begin{tabular}{|c|c|c|c|c|}
\hline \multirow{2}{*}{ Model Pembelajaran } & \multicolumn{3}{|c|}{ Kecerdasan Emosional } & Rerata \\
\cline { 2 - 4 } & Tinggi & Sedang & Rendah & Marginal \\
\hline TSTS & 74,29 & 70,73 & 70,96 & 71,07 \\
\hline Langsung & 73,21 & 57,22 & 35,37 & 56,86 \\
\hline Rerata Marginal & 73,80 & 63,62 & 53,51 & - \\
\hline
\end{tabular}

\section{PEMBAHASAN}

Berdasarkan hasil perhitungan ANAVA diperoleh H_0Aditolak, sehingga perlu dilakukan uji Scheffe. Perhitungan uji lanjut anava rerata antar baris ditunjukkan pada Tabel 3 .

Tabel 3 Perhitungan Uji Lanjut Anava

\begin{tabular}{|c|c|c|c|}
\hline$H_{0}$ & $F_{\text {obs }}$ & $2 F_{0,05 ; 2 ; 259}$ & Keputusan Uji \\
\hline$\mu_{1 .}=\mu_{2}$ & 6,11 & $(2)(3,000)=6,000$ & $H_{0}$ ditolak \\
\hline
\end{tabular}

Dari Tabel 3 dan rerata marginal pada tabel 2 (a) siswa yang diberi model pembelajaran TSTS memiliki prestasi belajar matematika lebih baik dibandingkan dengan siswa yang diberi model pembelajaran langsung. 
Kemudian seperti penelitian yang dilakukan oleh Fitriani, dkk (2011) danIdrisUmar, dkk (2014) menghasilkan kesimpulan sama yaitu model pembelajaran tipe TSTS dapat memberikan prestasi belajar yang lebih baik dibandingkan pada model langsung.

Berdasarkan perhitungan ANAVA diperoleh H_OB ditolak, sehingga perlu dilakukan uji lanjut ANAVA dengan metode Scheffe. Perhitungan uji lanjut anava rerata antar kolomdisajikan pada Tabel 4.

Tabel 4 Hasil Uji komparasai Rerata Antar Kolom

\begin{tabular}{|c|c|c|c|}
\hline$H_{0}$ & $F_{o b s}$ & $2 F_{0,05 ; 2 ; 259}$ & Keputusan Uji \\
\hline$\mu_{\mathrm{s} 1}=\mu_{r_{2}}$ & 6,36 & $(2)(3,000)=6,000$ & $H_{0}$ ditolak \\
\hline$\mu_{\mathrm{s} 1}=\mu_{r_{3}}$ & 57,61 & $(2)(3,000)=6,000$ & $H_{0}$ ditolak \\
\hline$\mu_{\mathrm{s} 2}=\mu_{r_{3}}$ & 26,11 & $(2)(3,000)=6,000$ & $H_{0}$ ditolak \\
\hline
\end{tabular}

Dari Tabel 4 dengan memperhatikan rerata marginal pada tabel 2, dapatdiperolehbahwa siswa dengan kecerdasan emosional tinggi mempunyai prestasi belajar yang lebih baik dibandingkan siswa dengan kecerdasan emosional sedang dan rendah. Siswa dengan kecerdasan emosional sedangmempunyai prestasi belajar yang lebih baik dibandingkan siswa dengan kecerdasan emosional rendah.

Selain itu penelitian yang dilakukan Ogundokun and Adeyemo (2012: 395-401) menunjukkan bahwa ada hubungan positif antara kecerdasan emosional dan prestasi akademik sehingga perkembangan kecerdasan emosional siswa akan mengarah pada peningkatan prestasi akademiknya.

Hasil perhitungan uji komparasi rataan antar sel pada kolom yang sama disajikan dalam tabel 5 sebagai berikut.

Tabel 5 Hasil Uji Komparasai Ganda Antar Sel pada Kolom yang Sama

\begin{tabular}{cccc}
\hline$H_{0}$ & $F_{o b s}$ & $8 F_{0,05 ; 8 ; 259}$ & Keputusan Uji \\
\hline$\mu_{11}=\mu_{21}$ & 0,96 & $(8)(1,94)=15,52$ & $H_{0}$ diterima \\
\hline$\mu_{12}=\mu_{22}$ & 17,01 & $(8)(1,94)=15,52$ & $H_{0}$ ditolak \\
\hline$\mu_{13}=\mu_{23}$ & 65,05 & $(8)(1,94)=15,52$ & $H_{0}$ ditolak \\
\hline
\end{tabular}

Pada siswa yang dominan pada kecerdasan emosional tinggi, tidak ada perbedaan rataan yang signifikan antara prestasi belajar siswa yang dikenai model pembelajaran TSTS dan model pembelajaran Langsung, sehingga siswa yang dikenai model pembelajaran TSTS dan model pembelajaran Langsung mempunyai prestasi belajar yang sama.

Pada siswa yang dominan pada kecerdasan emosional sedang, ada perbedaan rataan yang signifikan antara prestasi belajar siswa yang dikenai model pembelajaran TSTS dan model pembelajaran Langsung, Dilihat dari reratanya, maka prestasi belajar siswa yang dikenai model pembelajaran TSTS lebih baik daripada siswa yang dikenai model pembelajaran langsung.

Pada siswa yang dominan pada kecerdasan emosional rendah, ada perbedaan rataan yang signifikan antara prestasi belajar siswa yang dikenai model pembelajaran TSTS dan model pembelajaran Langsung, Dilihat dari reratanya, 
maka prestasi belajar siswa yang dikenai model pembelajaran TSTS lebih baik daripada siswa yang dikenai model pembelajaran langsung.

Hasil perhitungan uji komparasi rataan antar sel pada baris yang sama disajikan dalam tabel 6 sebagai berikut.

Tabel 6. Hasil Uji Komparasai Ganda Antar Sel pada baris yang Sama

\begin{tabular}{ccccc}
\hline & $H_{0}$ & $F_{o b s}$ & $8 F_{0,05 ; 8 ; 259}$ & Keputusan Uji \\
\hline a. & $\mu_{11}=\mu_{12}$ & 0,25 & $(8)(1,94)=15,52$ & $H_{0}$ diterima \\
\hline b. $\quad \mu_{11}=\mu_{13}$ & 0,09 & $(8)(1,94)=15,52$ & $H_{0}$ diterima \\
\hline c. $\quad \mu_{12}=\mu_{13}$ & 2,01 & $(8)(1,94)=15,52$ & $H_{0}$ diterima \\
\hline d. $\quad \mu_{21}=\mu_{22}$ & 25,48 & $(8)(1,94)=15,52$ & $H_{0}$ ditolak \\
\hline e. $\quad \mu_{21}=\mu_{23}$ & 89,15 & $(8)(1,94)=15,52$ & $H_{0}$ ditolak \\
\hline f. $\quad \mu_{22}=\mu_{23}$ & 13,51 & $(8)(1,94)=15,52$ & $H_{0}$ diterima \\
\hline
\end{tabular}

Pada siswa yang dikenai model pembelajaran TSTS tidak ada perbedaan rataan yang signifikan antara prestasi belajar siswa dengan kecerdasan emosional tinggi dan sedang, sehingga siswa dengan kecerdasan emosional tinggi dan sedang mempunyai prestasi belajar yang sama. Pada siswa yang dikenai model pembelajaran TSTS tidak ada perbedaan rataan yang signifikan antara prestasi belajar siswa dengan kecerdasan emosional tinggi dan rendah, sehingga siswa dengan kecerdasan emosional tinggi dan rendah mempunyai prestasi belajar yang sama. Pada siswa yang dikenai model pembelajaran TSTS tidak ada perbedaan rataan yang signifikan antara prestasi belajar siswa dengan kecerdasan emosional sedang dan rendah, sehingga siswa dengan kecerdasan emosional sedang dan rendah mempunyai prestasi belajar yang sama. Pada siswa yang dikenai model pembelajaran Langsung ada perbedaan rataan yang signifikan antara prestasi belajar siswa dengan kecerdasan emosional tinggi dan sedang, terlihat prestasi belajar siswa dengan kecerdasan emosional tinggi lebih baik daripada siswa siswa dengan kecerdasan emosional sedang. Pada siswa yang dikenai model pembelajaran Langsung ada perbedaan rataan yang signifikan antara prestasi belajar siswa dengan kecerdasan emosional tinggi dan rendah, terlihat prestasi belajar siswa dengan kecerdasan emosional tinggi lebih baik daripada siswa siswa dengan kecerdasan emosional rendah. Pada siswa yang dikenai model pembelajaran Langsung tidak ada perbedaan rataan yang signifikan antara prestasi belajar siswa dengan kecerdasan emosional sedang dan rendah, sehingga siswa dengan kecerdasan emosional sedang dan rendah mempunyai prestasi belajar yang sama.

\section{KESIMPULAN}

Berdasarkan analisis data dari penelitian yang dilakukan, dapat disimpulkan sebagai berikut: (1) siswa yang dikenai model pembelajaran TSTS mempunyai prestasi belajar matematika lebih baik dibandingkan siswa yang dikenai model pembelajaran langsung, (2) Siswa dengan kecerdasan emosional tinggi mempunyai prestasi belajar yang lebih baik dibandingkan siswa dengan kecerdasan emosional sedang dan rendah pada materi operasi hitung bentuk aljabar, serta siswa dengan kecerdasan emosional sedang mempunyai prestasi belajar yang lebih baik dibandingkan siswa dengan 
kecerdasan emosional rendah pada materi operasi hitung aljabar, (3) Siswa dengan kecerdasan rendah pada prestasi belajar matematika siswa yang dikenai model pembelajaran TSTS lebih baik dibandingkan prestasi belajar matematika siswa yang dikenai model pembelajaran langsung pada materi operasi hitung bentuk aljabar (4) Siswa yang dikenai model pembelajaran kooperatif tipe TSTS kecerdasan emosional tinggi, kecerdasan emosional sedang dan kecerdasan emosional rendah mempunyai prestasi belajar yang sama. Siswa yang dikenai model pembelajaran langsung prestasi belajar matematika siswa dengan kecerdasan emosional tinggi lebih baik dibandingkan siswa dengan kecerdasan emosional sedang dan rendah.

\section{SARAN}

Berdasarkan simpulan hasil penelitian di atas, penulis dapat memberikan beberapa saran sebagai berikut. Mengacu pada hasil penelitian yang menunjukkan bahwa model pembelajaran TSTS menghasilkan prestasi belajar yang lebih baik dibandingkan model pembelajaran langsung, maka disarankan kepada guru mata pelajaran matematika untuk menggunakan model pembelajaran TSTS. Sesuai dengan hasil penelitian ini yang menunjukkan bahwa kecerdasan emosional memberikan pengaruh terhadap prestasi belajar matematika, guru diharapkan untuk mengetahui kecerdasan emosional siswa.

\section{DAFTAR RUJUKAN}

Abdullah, M. C., Elias, H., Mahyuddin, R., \& Uli, J. 2004. Emotional Intelligence and Academic Achievement Among Malaysian Secondary Student. Pakistan Journal of Psychological Research, 19(4): 105-121.

Adeneye, O.A.A., Abayomi, A.A., \& Awofala, A.A. 2013. Effects Of Framing And Team Assisted Individualised Instructional Strategies On Senior Secondary School Students' Attitudes Toward Mathematics. Acta Didactica Napocensia, Vol.6(1): 1-22.

Ajaja, O.P. \& Eravwoke, O.U. 2010. Effects of Cooperative Learning Strategy on Junior Secondary School Students Achievement in Integrated Science. Electronic Journal of Science Education, 14(1):1-18.

Maria, C.A., Elias, H., Mahyuddin, R., \& Uli, J. 2004. Emotional Intelligence and Academic Achievement Among Malaysian Secondary Students. Pakistan Journal of Psycological Research. 19(4): 105-121.

Egodawatte, G. 2009. Secondary School Students' Misconceptions in Algebra. Acta Didactica Napocensia, 2(4): 101-106.

Fitriani T. D., Wawan W., \& Heli S. H. M. 2013. Pengaruh Penerapan Model Kooperatif Tipe Two Stay Two Stray Terhadap Kemampuan Berkomunikasi Siswa Pada Topik Aplikasi Reaksi Reduksi Oksidasi. Jurnal Riset dan Praktik Pendidikan Kimia. 1(1): 11-17.

Herman Hudojo. 2005. Pembelajaran Matematika. Malang : Penerbit Universitas Negeri Malang.

Hurlock, E.B. 2002. Psikologi Perkembangan. terj. Istiwidiyanti \& Soedjarwo. Jakarta: Erlangga.

Idris Umar, Soesamto, \& Sunyoto. 2013. Perbedaan Hasil Belajar K3 Menggunakan Model Pembelajaran TSTS Dan NHT. Journal of Mechanical Engineering Learning. 2 (1).

Nwadinigwe, I.P., \& Azuka-Obieke, A. 2012. The Impact of Emotional Intelligence on Academic Achievement of Senior Secondary School Students in Lagos, Nigeria. Journal of Emerging Trendin Educational Research and Policy Studie. 3(4): 395-401. 
Nyman, R. 2015. Indicators of student engagement: What teachers notice during introductory algebra lessons. International Journal for Mathematics Teaching and Learning.

Ogundokun, M.O. \& Adeyemo, D.A. 2012. Emotional Intelligence and Academic Acievement: The Moderating Influence Of Age, Intrinsic and Ekstrinsic Motivation. An Online Journal of The African Education, 10(2): 127141.

Patton, B. 2012. Analyzing Algebraic Thinking Using "Guess My Number" Problems. International Journal of Instruction. Vol.5(1): 5-22.

Zulkardi, M., \& Purwoko. 2009. Pengembangan Materi Integral untuk Sekolah Menengah Atas (SMA) Menggunakan Pendekatan Pendidikan Matematika Realistik Indonesia (PMRI) di Palembang. Jurnal Pendidikan Matematika. 3(1): 61-74. 